\title{
THE RESEARCH OF CHANGES IN ENVIRONMENTAL AND ECONOMIC BEHAVIOUR OF HOUSEHOLDS IN THE CZECH REPUBLIC
}

\author{
Zdeněk Hruška, Lilia Dvořáková
}

\section{Klíčová slova:}

ekologická daňová reforma, ekologické daně, životní prostředí, domácnost

\section{Key words:}

ecological tax reform, environmental taxes, environment, household

\begin{abstract}
Abstrakt
Článek obsahuje aktuální vědecké poznatky z problematiky ekologického zdanění v České republice. Je zaměřen na analýzu vlivu dopadu ekologického zdanění na domácnosti v České republice a na zjištění informovanosti českých domácností v oblasti ekologického zdanění. V článku jsou analyzována důležitá zjištění plynoucí z provedeného průzkumu u celkem 102 domácností a formulována doporučení pro státní orgány v budoucích etapách probíhající ekologické daňové reformy.
\end{abstract}

\begin{abstract}
The article contains actual scientific knowledge in environmental taxing in the Czech Republic. It is focused on the influence of environmental taxing impact analysis on households in the Czech Republic and on detection of Czech households' awareness in the environmental taxing area. In the article important discoveries arising from the research by 102 households are analysed. Recommendation for the state authorities is stated for the future stages of the ongoing ecological tax reform.
\end{abstract}

\section{Introduction}

The development of chemical, engineering, automotive and other industries has brought excessive overloading of the environment. Here we can refer to Jílková [10] who created the scheme of the relation between the economy and the environment. In the 20th century the issue started to be solved from the global perspective. The representatives of individual countries started to consider the establishment of the way leading to sustainable development and to limitations of environment pollution. Environmental taxes (also called energetic taxes or environment protection taxes) are one of the legislative instruments which should help to limit the environmental pollution and to direct the polluters to ecological production processes [4], [11], [14]. Environmental taxes should also stimulate the population to more considerate behaviour towards the environment (e.g. change of house heating from coal to more ecological types, purchase of a less polluting car, buying more economical household appliances). Environmental taxing should lead to limitations of non-renewable resources utilization and to concentration mainly on renewable resources, i.e. to support the implementation of sustainable production and consumption concept. The environmental taxes should also start the innovation development, greater use of renewable energy sources and therefore to improve the environment. [1], [14], [16]. Environmental taxes should bring double benefit. The first benefit should be the improvement of environment and the second one would be gaining new revenues for state [9]. 
A questionnaire was made up for the purpose of this article for the research of environmental taxing influence on households in the Czech Republic. Closed and semi-open questions enabled the respondents to complete their answers and needed information was obtained. Also filter questions were put in the questionnaire because they separate those respondents who hadn't noticed the introduction of environmental taxes into the Czech taxing system. After answering and evaluating all the questions in the questionnaire it was necessary to make additional inquiries. The results can also be found in the body of the article.

\section{Genesis and development of environmental taxing in the Czech Republic}

In the Czech Republic the environmental taxing in the true sense was introduced in 2008, although it was entered in the collections of The Law no. 212/1992 about taxing system with efficiency from 1993. The Czech Republic lay within the exception coming from the EC Directive 2004/74 until then. It involved natural gas, solid fuels and electrical energy. Discussions about introducing environmental taxing, or about starting the ecological tax reform were ongoing since about the second half of the nineties of the 20th century. The first official draft of the ecological tax reform was prepared by the Ministry of Environment of the Czech Republic and the Ministry of Finance of the Czech Republic in 2000 but the ecological tax reform was not started again [4]. On 1st. January 2008 the ecological tax reform which consists of three stages was initiated (see picture 1). The first stage took place in 2008 - 2009 when the natural gas and some other gases tax was introduced as well as the solid fuels tax and the electricity tax. In 2010 - 2013 the second stage of the ecological tax reform is being realized. Its result should be transfering of some environmental fees to environmental taxes and focusing on transport taxation. The third stage will go on in 2014 2017. The content of this last stage, for the time being, should be the reaction on the process of the two previous stages. Generally, further extension of environmental taxing can be pressumed [15].

The administrator of environmental taxes in the Czech Republic are the customs authorities which also issue permits to acquire free energy products and permits to acquire energy products without tax.

\section{Picture 1: Ecological tax reform in the Czech Republic}

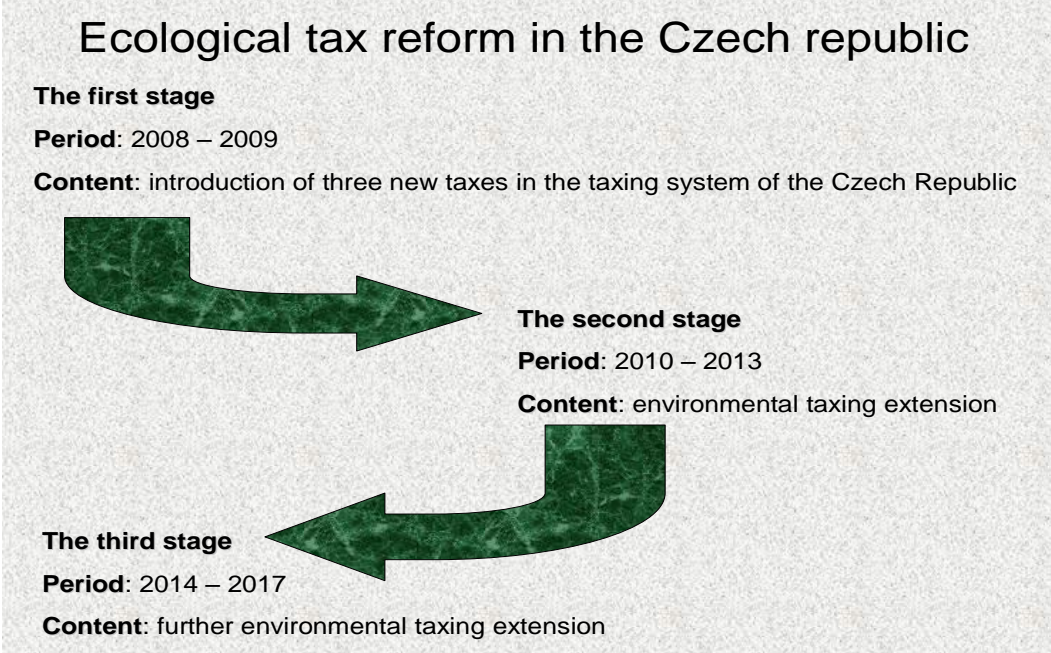

Source: [2], [15] own processing 


\section{Substantive and procedural requirements of environmental taxes in the Czech Republic}

The subject to solid fuels tax is particularly black and brown coal, coke, semi-coke and other hydrocarbons named in the law. For the tax on electricity the subject to tax is electricity indicated in the nomenclature code 2716. For the tax on natural and other gases the subject is gas stated in the law.

The environmental tax payer is the supplier or other subjects stated in the law. The taxpayer is required to submit a proposal to tax registration by the customs office at the latest on the day when the tax is required to be granted and paid.

The solid fuels tax base is made by the amount of solid fuels expressed by GJ of combustion heat. The electricity tax base is formed by the amount of electricity in MWh. And for the natural and other gases tax base is amount of gas in MWh of combustion heat. The tax rate for the solid fuels tax is $8.50 \mathrm{CZK} / \mathrm{GJ}$ of combustion heat, for the electricity tax it is 28.30 CZK/MWh. The natural and other gases tax rates are presented in table 1 . The tax duty of all three environmental taxes is calculated by the equation:

$$
D P=S * Z D
$$

Where: $D P$....tax duty

$$
\begin{aligned}
& S . . . . . \text { tax rate } \\
& Z D \text {...tax base }
\end{aligned}
$$

The legislation names a lot of exemptions of particular environmental taxes, e.g. solid fuels for electricity production, environmental friendly electricity (from solar or wind energy) or gas for household heat production. The Czech Republic as one of many countries prefers the natural gas heating as the most ecological. Therefore the gas used for heat production in households and house heating rooms is free of environmental tax [13], [19].

In the Czech Republic the taxing period for environmental taxes is calendar month and the tax report has to be handed in by the payer (and the tax has to be paid) by the twenty-fifth day after the end of the taxing period which the tax duty appeared in [19].

Table 1: Natural gas and other gases tax rates

\begin{tabular}{|l|r|c|}
\hline \multicolumn{1}{|c|}{ Nomenclature code / purpose } & \multicolumn{1}{c|}{ Tax rate } & \multicolumn{1}{c|}{ Period } \\
\hline 271129,2705 & $264,80 \mathrm{CZK} / \mathrm{MWh}$ & \multicolumn{1}{c|}{} \\
\hline 271111,271121 & $34,20 \mathrm{CZK} / \mathrm{MWh}$ & $1.1 .2012-31.12 .2014$ \\
\hline 271111,271121 & $68,40 \mathrm{CZK} / \mathrm{MWh}$ & $1.1 .2015-31.12 .2017$ \\
\hline 271111,271121 & $136,80 \mathrm{CZK} / \mathrm{MWh}$ & $1.1 .2018-31.12 .2019$ \\
\hline 271111,271121 & $264,80 \mathrm{CZK} / \mathrm{MWh}$ & From 1. 1.2020 \\
\hline Gas for heat production & $30,60 \mathrm{CZK} / \mathrm{MWh}$ & - \\
\hline Gas for other purposes $($ see $\S 4$ letter c) & $30,60 \mathrm{CZK} / \mathrm{MWh}$ & - \\
\hline & & Source: [19], own processing \\
\hline
\end{tabular}

Except three already valid environmental taxes, the state is considering introduction of carbon tax (emission components of existing energy tax), which would increase the coal price. This tax is not new, it is already implemented mainly in nothern countries such as Sweden and Finland, and it has been introduced in Australia the most recently. Obviously this tax would have an impact mainly on households (it could effect estimated 2 mil. households) 
and smaller businesses [6]. Big heating companies will not be involved in this taxing because the emission permits system applies to them. This tax should serve as a motivational factor for $\mathrm{CO} 2$ emission reduction. However it is necessary to realize if the majority of subjects affected by this tax will be motivated to investment leading to lower $\mathrm{CO} 2$ production. We must consider households with lower income which are not connected to gas and therefore they heat only by coal. Such households have basically two options (if we exclude electricity heating which is suitable just for new low energy constructions). To invest in changing the heating system (gas, heat pumps, solar panels etc.) which means not small investments or to start heating with wood more or, in the worst case, to start burning waste. The result of carbon tax introduction might be quite contrary. It means that some subject could produce more $\mathrm{CO} 2$ emissions instead of reducing these emissions.

At the same time, the carbon tax should serve as a quite stable income for the state budget (it is expected to bring about 7 billion CZK a year into the state treasury). Nevertheless the government should respect the rule of revenue neutrality of environmental taxes. It should be at least partly ensured by the reduction of value-added tax which is supposed to be reduced from current $20 \%$ to $17.5 \%$ since 2013 by coal and natural gas. Introduction of the carbon tax is planned just for 2013. The amount of carbon tax is 20 EUR for 1 ton of emissions [7], [8].

\section{The influence of environmental taxes on households in the Czech Republic}

Environmental taxes have affected Czech households although with meeting the basic pressumption of revenue neutrality. Especially households of retired citizens because possible reduction of production factor taxing will not bring any relief to them. We can see a hard impact of environmental taxing on those households which do not have the resources to invest in energy saving equipment, i.e. low income households. There are approximately 40 $\%$ of the poorest residents [16]. A different impact of environmental taxes on households is also connected with the location and the way they produce heat. If they produce the heat independently or if they are supplied by a central source (so-called remote heating). If the result of environmental taxes is reduction of environment pollution, the central (remote) sources of heating should be preferred. Presently the central heating system or cogeneration is used by about 1.5 mil households, especially majority of schools, hospitals, companies and other institutions. Thanks to the high efficiency of cogeneration we can get higher effectiveness (up to $40 \%$ emission savings) during the burning process in contrast with households using local heating devices [18].

The revenue neutrality should have been reached after introducing the environmental taxes from 2008 by reducing the contribution for social insurance of employees and self-employed people. Czech public do not have much information about this reduction of contribution as we can see from the results of the questionnaire. By others the citizen groups which could not enforce this deduction, the revenue neutrality was not accomplished. They are among others: unemployed people, mothers on maternity leave, parents on parental leave, retired people, students, citizens on sick leave etc. The environmental taxes have had a negative impact especially on family budgets of these citizen groups. The revenue „non-neutrality“ showed in their cases [13].

A questionnaire survey was done by 102 households from regions of all the Czech Republic for environmental taxes impact on households analyses. The original sample consisted of 111 households. The return of the questionnaires was $92 \%$. The age of respondents ranged from 
18 to 73 years. The results of the survey are supported by numeral data. The research was conducted by personal contact and inquiry.

The research was primarily focused on the environmental and economic behavior of households and the research was dividend into 9 steps. The key steps in the research were the fourth, fifth, seventh, eighth and ninth step.

At the first step of questioning we were detecting how many members an interviewed household has. We found out that one household has one member, twenty-six households have two members, twenty-one households have three members, forty-two households have four members and remaining twelve households have more than four members.

At the next step the target was to find out what kind of heating the households use. Out of the questioned households thirty-four use solid fuels (mainly coal and briquettes) for heating their flats and houses, eighteen use electricity, forty-nine use gas and fifteen use another kind of heating. Some households use a combined way of heating, therefore they ticked more options.

Picture 2: Ways of heating flats and houses by interviewed households

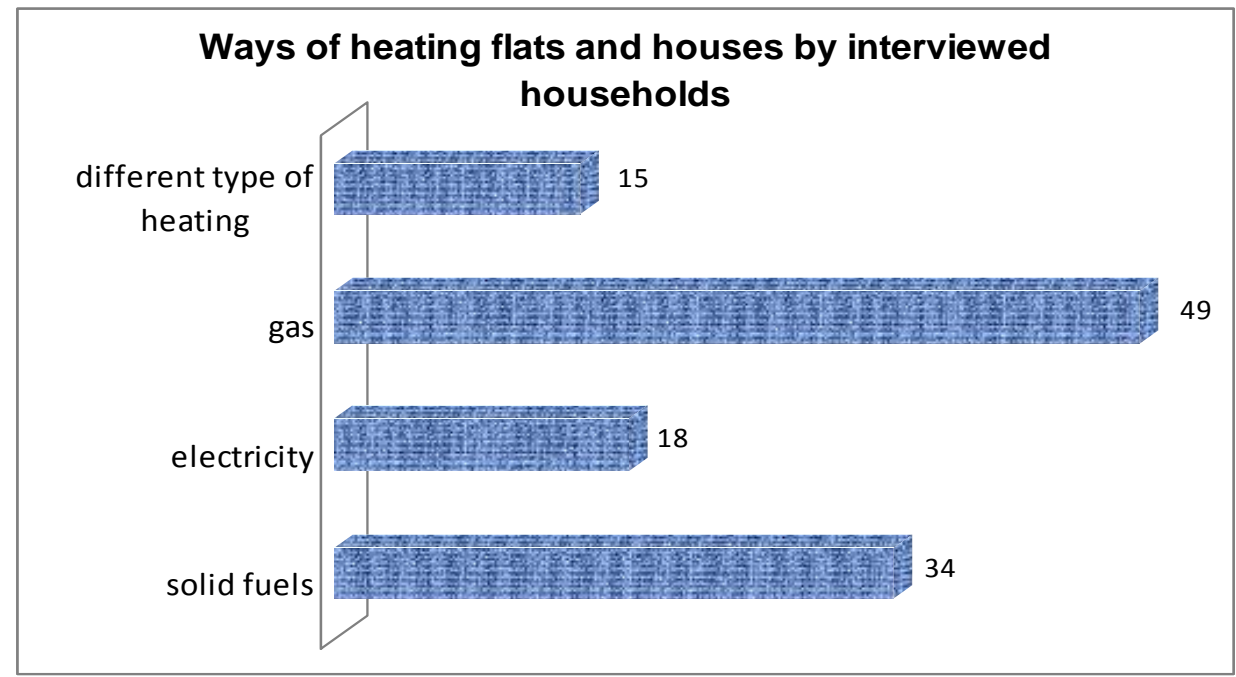

Source: own research

The third step of questioning should determine whether Czech households noticed increase of energy prices and of what amount approximately. Out of the total amount of questioned households ninety-six households have noticed the increase in energy prices since $1^{\text {st }}$ January 2008. However it is not clearly identified if it was a rise caused by common annual increase in energy prices or a rise for environmental taxes introduction reason. Most of the households (49) cannot determine the exact amount by which the price was increased monthly. Thirtyfive households estimated the amount between 200 - 2000 a month and five households even higher.

The crucial part of the survey was the forth step where the target was to find out if Czech households are aware of introduction of environmental taxes in the Czech taxing system. The results show that the state informed the public insufficiently about the ecologization of the taxing system because thirty-eight households out of the total number of respondents (37\%) did not notice the introduction of environmental taxes in the Czech Republic at all, as you can see in picture 3 . If the environmental taxes should have a motivational influence on not only businesses but also households concerning the investments leading to energy saving and more environmental-friendly behaviour (e.g. purchase of solar panels, exchange the solid fuels 
heating for gas heating, investment in ecological boilers or investments in appliances with significantly lower electricity consumption or house insulation), the households must be aware of the existence of environmental taxes. The households should be informed not only about their existence itself but in the sense of which amounts are valid within the environmental taxes in energy products prices. Only then some further steps can follow leading to environmental improvement.

Picture 3: Awareness of Czech households about the ecologization of the Czech taxing system

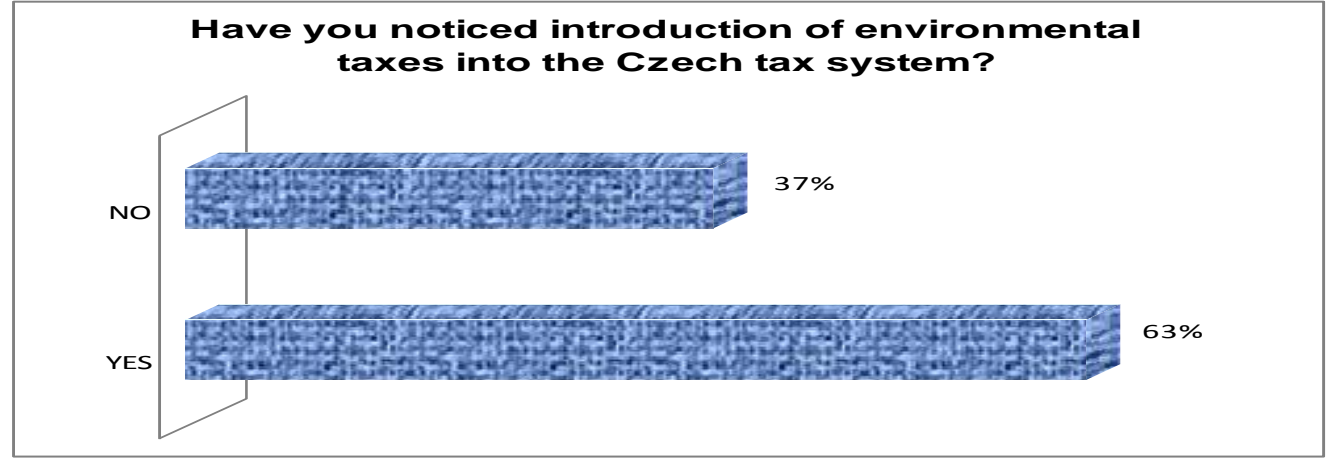

Source: own research

Bad awareness of Czech public about environmental taxing is confirmed by the fifth step of the research which investigates which environmental taxes relate to individual households. Some households which heat with solid fuels did not know that solid fuels have been taxed by the solid fuel tax since 2008. And on the contrary the households which use gas for heating wrongly believe that the gas price involves the gas tax. But gas for heating is free of this tax. All questioned households use electricity so it could be expected that most of them answer that the electricity tax applies to them. However only forty-eight households realize that they pay the environmental tax within the price of electricity.

In the sixth step sixty-four households which had noticed the introduction of environmental taxes in the Czech taxing system later answered the question if introducing the environmental taxes caused their higher expenses within the energy products price rise. Some people who do not know about environmental taxes answered this question too. As picture 4 shows thirty of them (40\%) noticed a slight growth, seventeen a high growth (22\%) and twenty-five households $(33 \%)$ are not able to identify the growth as a result of introducing the environmental taxing. It shows that there are great differences in the awareness about environmental taxing among Czech households. During the additional inquiries among those households which had noticed the introduction of environmental taxes a very important fact was found out. They found out about the introduction of environmental taxing mainly from massmedia and a great majority of them had to look for the price increase caused by the introduction of the environmental taxes themselves. 


\section{Picture 4: Influence of the environmental taxes introduction on Czech households' expenses}

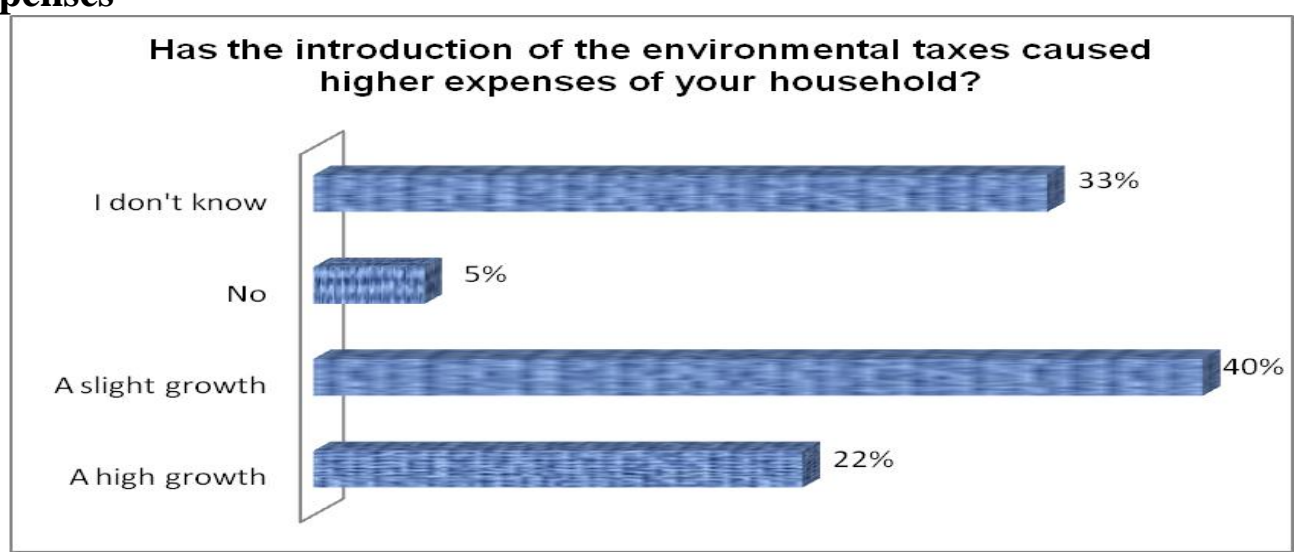

Source: own research

The seventh step had a target to find out if Czech households are motivated by introducing the environmental taxes to changes in energy consumption and production. It means mainly the purchase of solar panels for electricity production which is used also for heating and investments which are stated above. As picture 5 illustrates, fifty-eight households out of seventy-two responding $(81 \%)$ haven't made any changes and haven't even considered any. Fourteen of them invested mainly in the purchase of solar panels or energetically less demanding appliances (especially fridges and washing machines) or these households consider such investments in the future. An interesting partial result is that nearly half of the interviewed households (those who have noticed the introduction of the environmental taxes) think that the environmental tax included in the electricity price is much higher than it really is and after the introduction of environmental taxes they invested mainly in energy-saving household appliances. This was found out by semi-open questions also by households which use solid fuels heating (especially coal). These households preferred investing in energysaving household appliances to investing in a more ecological way of heating.

A part of the seventh step was investigation on how would the households which use solid fuels heating ( 34 households out of 102 questioned) react to the introduction of carbon tax. The result was dismal from the environmental point of view because 15 households (44\%) answered that they would start burning households' waste. Only 8 households are planning to invest in another way of heating and 11 households stated that they will heat with wood more. A very serious consequence comes out of this partial survey and it is a possible opposite effect of the carbon tax. According to the survey the carbon tax would not lead to reduction of households' harmful emissions but on the contrary to their increase thanks to waste burning. That is why its possible introduction should be accompanied by other regulations (monitoring households' fuels or support by state financial contribution to purchase of boilers which do not enable waste burning). Above that, if households decide to heat with wood because of the carbon tax, there is threat of forest looting although in two years $(2009-2011)$ the price of heating wood was stable and it does not show any significant fluctuation [17]. 


\section{Picture 5: Reaction of households to environmental taxes introduction}

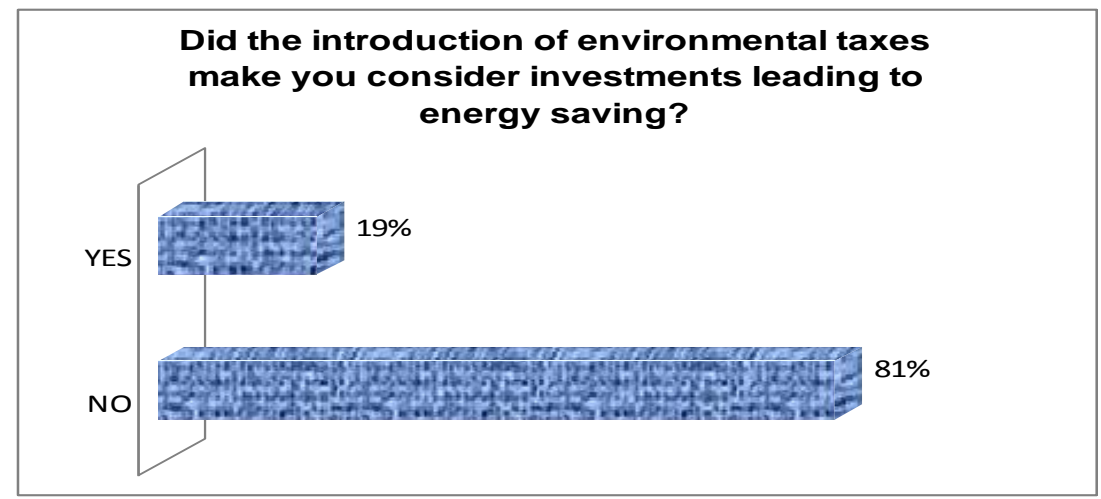

Source: own research

A part of the research was to find out how Czech households perceive ecologization of the Czech tax system. An unclear result arose by the eighth step when, as picture 6 shows, twenty-seven households (36\%) see the environmental taxes as a state tool to increase fiscal income, twenty-four (32\%) as a necessary tool to protect the environment and application of sustainable development, the rest of respondents do not have a clear opinion (some people who do not know about environmental taxes answered this question too and results were processed). Also here we can see the problem of bad awareness of households about the ecologization of the Czech tax system when the environmental taxes should mainly serve as a state environmental policy tool to protect the environment. However a problem arises as early as by the approval of environmental taxes in the Czech tax system itself. Their introduction in the Czech Republic was not primarily completed for environmental reasons but for reasons resulting from EC Directive 2003/96 which defines the minimal environmental tax rates in European Union member states [20]. The Czech Republic applied to an exception coming from EC Directive 2004/74 till the end 2007. The awareness of Czech households is on a very bad level also regarding the basic principles of environmental taxes, mainly regarding their revenue neutrality principle.

Picture 6: Understanding the environmental taxing by Czech households

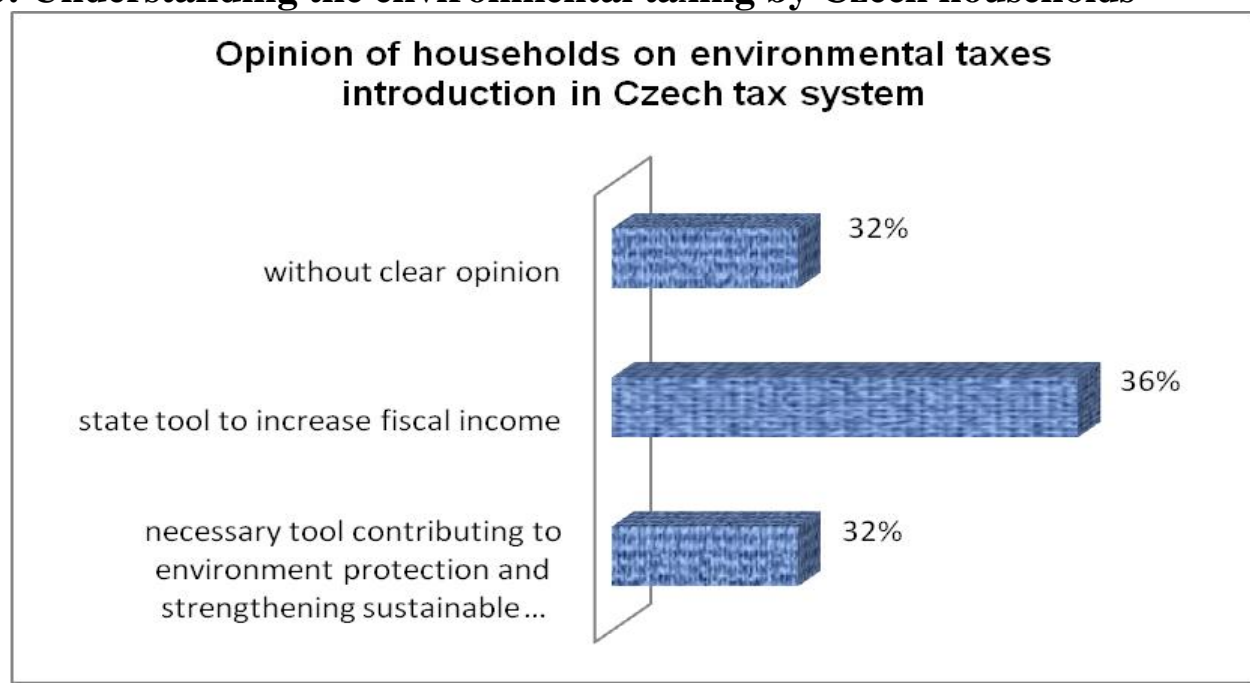

Source: own research

A relatively clear result is coming from the last ninth step of the research when the target was to find out the opinion of households on the future development of environmental taxing. The interviewed households are definitely expecting further increase in environmental taxes and 
extending their amount (see picture 7). It is very probable that these households will adjust their expenses in family budgets, they will follow the suggesting and approving process of legislative changes concerning the environmental taxes, they will take the change of heating system into account and they will be better prepared for possible increase of current environmental taxes or introducing new kinds of environmental taxes. Only two of the questioned households think that environmental taxes will be reduced and three households stated the opinion that environmental taxes will be abolished and substituted by another form of taxing.

Picture 7: Czech households' opinion on the future development of environmental taxing

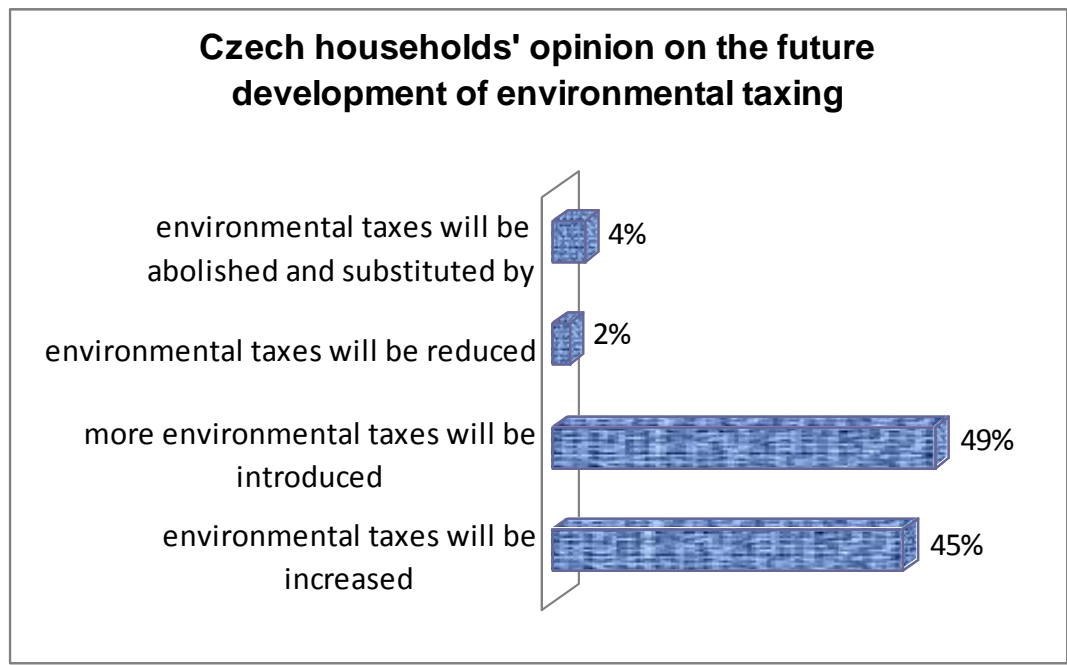

Source: own research

\section{Expenses increase of an average Czech household due to environmental taxation}

The research includes the evaluation of the impact of environmental taxation without their entering into the calculation of tax base of value added tax. The illustration of expenses increase of an average Czech household due to the introduction of environmental taxation was based on the assumption that a household has four members, they live in a detached house, they heat with coal and use gas only for cooking. Another assumption was that the household consumes 5 tons of coal a year (which is $165 \mathrm{GJ}$ a year considering $33 \mathrm{GJ}$ combustion heat for 1 ton of coal) [12] and 4 Mwh of electricity [5].

Such a model household paid $1420,50 \mathrm{CZK}$ more for coal a year due to the introduction of environmental taxes on solid fuels $(8,50 * 165)$. For electricity they paid $113,20 \mathrm{CZK}$ a year more due to the introduction of environmental taxes on electricity $(4 * 28,30)$. Gas for cooking (as well as for heating) is free of tax on natural and some other gases in the Czech Republic (however the Minister of Finance of the Czech Republic has suggested its taxation and the issue has not been closed yet), therefore there is no increase in the expenses of Czech households due to the introduction of environmental taxes on natural gas and some other gases.

The completed calculations show that the average yearly expenses were increased for more than $1500 \mathrm{CZK}$ a year for an average Czech household living in a detached house. For households living in a flat the environmental taxing will be reflected in the price increase of heat delivered by heat companies and also in the electricity price increase. On the contrary the 
households heating with gas did not notice the introduction of the environmental taxes because gas for heating is free of tax.

As Ekins and Speck present [4], the introduction of the environmental taxes in the Czech Republic has meant $10 \%$ increase in price of coal, coke and semi-coke and $1 \%$ increase in electricity price for the households since 2008. In the Czech Republic the introduction of the environmental taxes did not have a full impact on households because there has been effort to respect the revenue neutrality in the form of introducing the natural person income tax with a fixed rate of $15 \%$ and in 2009 reduction of social security rate for $1,5 \%$. Both measures do not relate to retired people households which have been effected by the introduction of the environmental taxes in full strength especially retired people living in small villages without gas connection.

\section{Conclusion}

The results of the research identify the situation in the field of environmental taxation in the Czech Republic after three years of existence of environmental taxes. The results of the research showed that there were no significant changes in ecological and economic behavior of households in this period.

The completed research shows that Czech households noticed the price increase after the introduction of the environmental taxes but another output of the research adds that Czech households have little information about the ecologization of the Czech taxing system (37\% of households do not know about environmental taxes) and therefore they are mostly not able to identify if their expenses growth was caused by environmental taxing. Little transparent and motivational system setting is proved by the findings that Czech households get information almost exclusively from massmedia and the state is failing in presenting the citizens information about the legislative changes. The state should also care about the regressive impact of environmental taxes mainly on low-income households and households of retired people during the second and third stage of the ecological tax reform (see more Ekins, Pollit [3]). It could be realized in the form of tax allowance, financial support, energy savings support (e.g. house insulation support) or more environmental-friendly heating support.

The conducted survey showed that only $19 \%$ of households realised investments leading to saving of energy products. Another important result of the research is the opinion of households on tax system ecologization in the Czech Republic. Only $32 \%$ of interviewed households see environmental taxes as a tool for environment protection and more than $90 \%$ of households expect the environmental taxes in the Czech Republic to be increased or extended. In this respect the state should try to give more information about the reason for introducing the environmental taxes to prevent negative opinion of Czech households on them because environmental taxes are one of the possible tools for creating new work positions. By respecting the revenue neutrality the tax burden of work production factor should be reduced and the burden should be moved to polluters which is very positive for the economics in the final result. Higher awareness should also lead to higher motivation of households to invest in more environment-friendly way of heating or to save energy more.

The article was processed with the project SGS-2012-022 „Financial management theory and practice development" support. 


\section{Literature:}

[1] BOSQUET, B. Environmental tax reform: does it work? A survey of the empirical evidence. Ecological Economics, 2000, Iss. 1, Vol. 34, pp. 19-32. ISSN 0921-8009.

[2] Centrum pro otázky životního prostředí. [online]. Praha: Platforma pro environmentální fiskální reformu v ČR, [cit. 2012-12-05]. Available on: $<$ http://www.czp.cuni.cz/ekoreforma/cz/>.

[3] EKINS, P., POLliTT, H., BARTON, J. and BLOBEL, D. The implications for households of environmental tax reform (ETR) in Europe. Ecological Economics. 2011, Iss. 12, Vol. 70, pp. 2472-2485. ISSN 0921-8009.

[4] EKINS, P., SPECK, S. Environmental tax reform. 1. vydání. New York: Oxford University Press Inc., 2011, 371 s. ISBN 978-0-19-958450-5.

[5] Energetika.cz. [online]. Praha: Úspory elektřiny v domácnosti, [cit. 2011-11-29]. Available on: <http://www.energetika.cz/?id=71\&cl=356>.

[6] EnviWeb. [online]. Brno: Bezplatné povolenky jsou přiděleny. Na řadě je uhlíková daň, [cit. 2011-11-18]. Available on: <http://www.enviweb.cz/clanek/vzduch/88267/ bezplatne-povolenky-jsou-prideleny-na-rade-je-uhlikova-dan>.

[7] EnviWeb. [online]. Brno: Zavede Kalousek uhlíkovou daň?, [cit. 2011-11-20]. Available on: <http://www.enviweb.cz/clanek/energie/89101/zavede-kalousek-uhlikovou-dan>.

[8] Finanční noviny. [online]. Praha: Emisní povolenky budou zdarma, lidé zaplatí vyšší daň, [cit. 2011-11-18]. Available on: <http://www.financninoviny.cz/zpravy/emisnipovolenky-budou-zdarma-lide-zaplati-vyssi-dan/690227>.

[9] FULlERTON, D., LEICESTER, A. and SMITH, S. Environmental taxes. National Bureau of Economic Research [online]. Cambridge. 2008, [cit. 2012-12-06]. Available on: 〈http://www.nber.org/papers/w14197.pdf?new_window=1>.

[10] JÍLKOVÁ, J. Daně, dotace a obchodovatelná povolení - nástroje ochrany ovzduši a klimatu. 1. vydání. Praha: IREAS, Institut pro strukturální politiku, o.p.s., 2003. 157 s. ISBN 80-86684-04-0.

[11]KLOK, J. Energy taxation in the European Union. Past negotiations and future perspectives. Instituto de estudios fiscales [online]. Madrid. 2005, [cit. 2012-12-08]. Available on: $<$ http://www.ief.es/documentos/recursos/publicaciones/documentos_trabajo/2005_21.pdf $>$

[12] Nazeleno.cz. [online]. Brno: Ekologická daň zdražila uhlí i elektřinu. Co bude dál?, [cit. 2011-11-28]. Available on: <http://www.nazeleno.cz/vytapeni/ekologicka-dan-zdrazilauhli-i-elektrinu-co-bude-dal.aspx $>$.

[13]Penize.cz. [online]. Praha: Ekologická daň zdraží topení uhlím a elektřinou, [cit. 2011-1125]. Available on: <http://www.penize.cz/spotrebitel/29424-ekologicka-dan-zdrazitopeni-uhlim-a-elektrinou>.

[14]PLAMÍNKOVÁ, J. U ekologické daňové reformy je nutný dialog s veřejností. TZB-info [online]. Praha. 2003, [cit. 2012-12-09]. Available on: <http://www.tzb-info.cz/1707nedelni-editorial-u-ekologicke-danove-reformy-je-nutny-dialog-s-verejnosti $>$.

[15]SVÁTKOVÁ, S. Spotřební a ekologické daně v České republice. 1. vydání. Praha: Wolters Kluwer CR, a. s., 2009. 300 s. ISBN 978-80-7357-443-7.

[16] ŠČASNÝ, M. Rodinný rozpočet daň nezasáhne. Hospodářské noviny [online]. Praha: 2003, [cit. 2012-12-08]. Available on: 〈http://hn.ihned.cz/c1-13531500〉.

[17] Technická zařizení budov. [online]. Vývoj cen paliv za poslední dva roky, nejvíce zdražily pelety, [cit. 2012-03-08]. Available on: <http://www.tzb-info.cz/ceny-paliv-aenergii/7409-vyvoj-cen-paliv-za-posledni-dva-roky-nejvice-zdrazily-pelety>. 
[18] Teplárenské sdružení České republiky. [online]. Změny v daňovém systemu mohou přinést zdražení dálkového vytápění, [cit 2011-11-30]. Available on: <http://www.tzbinfo.cz/4081-zmeny-v-danovem-systemu-mohou-prinest-zdrazeni-dalkoveho-vytapeni>.

[19]Zákon č. 261/2007 Sb. ze dne 19. záŕí 2007, o stabilizaci veřejných rozpočtů.

[20]ZIMMERMANNOVÁ, J., KORBA, K. Komparace zdanění $\mathrm{CO}_{2}$ v zemích Evropské unie. Acta Oeconomica Pragensia. 2010, ISSN 0572-3043.

\section{JEL H23, H31}

\section{Ing. Zdeněk Hruška}

Interní doktorand Katedra financí a účetnictví

Odborný asistent Katedra financí a účetnictví

Fakulta ekonomická

Západočeská univerzita v Plzni

Husova 11, 30614 Plzeň

Tel.: 377633221

hruskaz@kfu.zcu.cz

\section{Prof. Ing. Lilia Dvořáková, CSc.}

Vedoucí Katedra financí a účetnictví

Fakulta ekonomická

Západočeská univerzita v Plzni

Husova 11, 30614 Plzeň

Tel.: 377633200

ldvorako@kfu.zcu.cz 